\title{
The European Commission and pharmaceutical policy
}

\author{
A victory for profits over public health?
}

\author{
Martin McKee professor of European public health ${ }^{1}$, Paul Belcher strategic adviser to the president \\ and board ${ }^{2}$
}

${ }^{1}$ London School of Hygiene and Tropical Medicine; ${ }^{2}$ European Public Health Alliance

News of the allocation by the European Commission's president elect, Jean-Claude Juncker, of portfolios to the remaining European Commissioners has been eagerly awaited. This is an intensely political process, with the largest member states vying among themselves for the main economic roles. Would Juncker follow established precedent, giving health a low priority by allocating the portfolio to one of the countries with the smallest economies and thus, in effect, least political power in the European Union? This process had seen responsibility transfer, after European Union enlargement, from Ireland to Cyprus and then Malta. Or would he break with precedent and allocate it on the basis of merit, choosing the commissioner whose expertise and experience most closely matched the role?

This time it seemed at least possible that Juncker would choose the second course, given that the line up included a very experienced candidate, Vytenis Andriukaitis, a Lithuanian surgeon who had been active in his country's struggle for independence and gone on to become a successful health minister. European health policy experts were delighted when Juncker chose this course; subject to approval by the European Parliament, Andriukaitis will take up his role in November 2014.

Yet very shortly afterwards it became clear that the news was not all that it seemed. The allocation of jobs was accompanied by a restructuring of the directorates general (DGs) - in effect the ministries of the European Commission-without any explanation for the change. Three of the key units within the directorate general for health and consumers (DG SANCO) were to be transferred to the directorate general for the internal market, industry, and entrepreneurship (DG ENTR). These were the units responsible for medicinal products and medical devices, including authorisations; that for quality, safety and efficacy; and the European Medicines Agency.

This move reversed changes made by the previous European Union president, José Manuel Barroso, who in 2009 had brought these responsibilities within DG SANCO after a campaign led by pan-European health and consumer groups. ${ }^{1}$ Then, DG ENTR was seen as unable to provide the necessary leadership in the face of H1N1 influenza, especially in respect to emergency preparedness. The 2009 reorganisation also reflected a recognition of the need to harmonise the European Commission's structures with those of its member states, where policies on pharmaceutical quality and safety were typically led by health ministries.

Inevitably, the latest change has provoked a furious response among health policy experts. Peggy Maguire, president of the European Public Health Alliance, described it as a "potential disaster," arguing that Juncker was placing health concerns in "second place to appeasing big business." In the same vein Monique Goyens, director general of the European Consumer Organization, said, "This shift gives European consumers the signal that economic interests come before their health." ${ }^{2}$ In contrast, the body representing the European drug industry was delighted. Richard Bergstrom, director general of the European Federation of Pharmaceutical Industries and Associations, welcomed the move, expressing his "trust [that] the people in these units have the integrity to continue to put patient safety first." ${ }^{3}$

Critics of the transfer have three main objections. The first, and perhaps the most important at a time when the failures of the current model of pharmaceutical discovery and development have been unfolding in the glare of publicity surrounding the Ebola outbreak, ${ }^{4}$ is the question of how DG SANCO will be able to fulfil its mandates in respect of preparedness for infectious diseases, such as pandemic flu, and biological or chemical terrorism. One of the main components of any response will be the authorisation, monitoring, and allocation of drugs, which will now lie with the DG responsible for industry, whose mandate is to promote the competitiveness of the drug industry. In these circumstances there is a danger that commercial interests will trump health security.

The second concern relates to the best way to create incentives to bring new drugs to market. Some measures have focused on enhanced protection of intellectual property rights and thus the industry's profits. One example is how manufacturers have been rewarded for seeking approval to use their products in children, thereby avoiding potentially hazardous off-label prescribing, by being given extended patent life. The goal was certainly laudable, but its success has been questionable. ${ }^{5} \mathrm{New}$ 
mechanisms are certainly needed, but again they must balance the interests of the industry and the public, and the question is who is best placed to do this.

A third concern relates to the secrecy of the drug authorisation process, as described in great detail by Ben Goldacre in his book Bad Pharma. ${ }^{6}$ Glenis Willmott, a British member of the European Parliament, recalled, "When I was negotiating the transparency laws for clinical trial results, it was DG Enterprise that wanted to water the rules down. Now they will be overseeing the European Medicines Agency as it implements the transparency regime, which is frankly concerning."

A final concern, albeit one less openly voiced, relates to the challenge of transferring these responsibilities to a directorate general that is headed by a nominee of the Polish government, which has demonstrated its willingness to place corporate interests above those of public health in its opposition to tobacco control measures, ${ }^{7}$ even to the extent of over-ruling its health minister. In this respect Poland is rapidly assuming the role of the tobacco industry's best friend in Europe, a role previously held by Germany. ${ }^{8}$ There have also been concerns about apparently close ties between the pharmaceutical and medical technology industries and Polish regulators. ${ }^{9}{ }^{10}$

Recent national and European elections revealed a combination of disillusionment and outright hostility to the European idea. Taking responsibility for medicines from those charged with safeguarding public health and giving it to those whose goal is to support an industry whose track record is decidedly mixed seems a strange way to improve this situation.
Competing interests: We have read and understood BMJ's policy on declaration of interests and declare the following interests: MM is a member of the European Commission's Expert Panel on Investing in Health.

Provenance and peer review: Commissioned, not externally peer reviewed.

1 European Public Health Alliance, European Consumer Association (BEUC), Association Internationale de la Mutualité. Governance change needed: EU pharmaceutical policy should be the responsibility of a health focussed directorate within the European Commission. 2009. www.epha.org/IMG/pdf/Pharma_Policy_Competency_Letter_17-0609.doc.pdf.

2 European Public Health Alliance. Juncker puts Europe's security at risk by promoting profit over public health [press release]. 2014. www.epha.org/a/6153.

3 Hirschler B. EU under fire for making medicines industrial, not health issue. Reuters 2014 www.reuters.com/article/2014/09/12/eu-health-medicine-idUSL5NORD4V320140912.

4 Cooper C. Ebola outbreak: why has "Big Pharma" failed deadly virus' victims? Independent 2014. www.independent.co.uk/life-style/health-and-families/health-news/ebola-outbreakbig-pharma-failed-victims-why-9716615.html.

5 Rose K. Pediatric pharmaceutical legislation in the USA and EU and their impact on adult and pediatric drug development. In: Bar-Shalom D, Rose K (eds). Pediatric formulations: AAPS advances in the pharmaceutical sciences series. Springer, 2014:405-19.

6 Goldacre B. Bad pharma: how drug companies mislead doctors and harm patients. Fourth Estate, 2012.

7 Szary W. Poland to challenge EU ban on menthol cigarettes. Reuters 2014. http://uk. reuters.com/article/2014/07/21/uk-poland-tobacco-lawsuit-idUKKBNOFQ0QU20140721.

8 Gruning T, Gilmore AB, McKee M. Tobacco industry influence on science and scientists in Germany. Am J Public Health 2006;96:20-32.

9 Ozieranski P, McKee M, King L. Pharmaceutical lobbying under postcommunism: universal or country-specific methods of securing state drug reimbursement in Poland? Health Econ Policy Law 2012;7:175-95.

10 Ozieranski P, McKee M, King L. The politics of health technology assessment in Poland. Health Policy 2012;108:178-93.

Cite this as: BMJ 2014;349:95671

(C) BMJ Publishing Group Ltd 2014 